\title{
MARKETING CHANNELS ANALYSIS OF CARICA (Carica Pubescens) FARMING IN KEJAJAR DISTRICT, WONOSOBO REGENCY
}

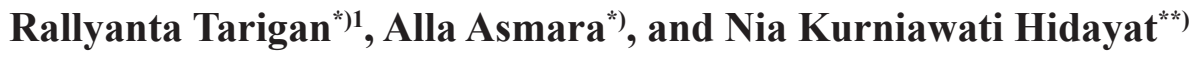 \\ ${ }^{*}$ Departemen of Economics, Faculty of Economics and Managemen, IPB University \\ Jl. Agatis, Campus of IPB Dramaga, Bogor 16680, West Java, Indonesia \\ ${ }^{* *}$ Departemen of Environmental and Resources Economics, Faculty of Economics and Managemen, IPB University \\ Jl. Agatis, Campus of IPB Dramaga, Bogor 16680, West Java, Indonesia
}

\begin{abstract}
The main problem of Carica farming in Kejajar District was the differences in farmers' prices in the collection and processing Carica fruit industry. The product marketed by the farmers was fresh Carica fruit and information about the minimum selling price caused them to be unable to determine the right institution. These problems affected Carica's marketing channel, leading to market inefficiencies. This study's place was selected purposively in Kejajar District, Wonosobo Regency, with the consideration that Kejajar Subdistrict is a Carica center with a production of 4,589 tons $(68 \%)$ of the total Carica production in Wonosobo Regency. The research was conducted from October - November 2020. The Structure Conduct Performance (SCP) method was used to analyze the marketing channels. The results of the marketing channel analysis show that the market structure formed at the farm level was in the form of a purely competitive market, and at the trader level, the market structure was formed by oligopoly. There were six Carica-marketing channels with cash payment systems, and the merchant determined the purchase price. The highest farmer's share and profit to cost ratio was channel I (farmer $\rightarrow$ processing industry) and VI (farmer $\rightarrow$ village collector $\rightarrow$ processing industry). The marketing efficiency analysis results show that the marketing of Carica was inefficient because the farmer's share at four marketing channels received by farmers was still less than $40 \%$.
\end{abstract}

Keywords: Carica (Carica pubescens), farming, marketing channels, marketing efficiency, $\mathrm{SCP}$

Abstrak: Permasalahan utama yang muncul berupa perbedaan harga yang diterima oleh petani di tingkat pengumpul dan industri pengolahan Carica. Harga dipengaruhi oleh pemilihan saluran pemasaran dalam memasarkan Carica. Produk yang dipasarkan oleh petani hanya dalam bentuk segar dan tidak dilakukan pengolahan sebelum dijual. Minimalnya informasi harga jual yang diterima petani menyebabkan petani tidak mampu menentukan kelembagaan yang tepat. Beberapa masalah yang disebutkan sebelumnya berpengaruh pada saluran pemasaran Carica sehingga menyebabkan inefisiensi pasar. Penelitian dilaksanakan di Kecamatan Kejajar, Kabupaten Wonosobo. Pemilihan lokasi penelitian dilakukan secara sengaja (purposive), karena Kecamatan Kejajar merupakan sentra Carica dengan produksi 4.589 ton (68\%) dari total produksi Carica di Kabupaten Wonosobo. Penelitian dilakukan pada bulan Oktober-November 2020. Metode Structure Conduct Performance (SCP) digunakan untuk menganalisis saluran pemasaran. Hasil analisis saluran pemasaran menunjukkan struktur pasar yang terbentuk pada tingkat petani berupa pasar persaingan murni dan pada tingkat pedagang struktur pasar yang terbentuk oligopoli. Terdapat enam saluran pemasaran Carica dengan sistem pembayaran tunai dan harga beli ditentukan oleh pedagang. Saluran pemasaran yang memiliki farmer's share dan rasio keuntungan terhadap biaya tertinggi berada pada saluran I (petani $\rightarrow$ industri pengolah) dan VI (petani $\rightarrow$ pengumpul desa $\rightarrow$ industri pengolah). Hasil analisis efisiensi pemasaran menunjukkan bahwa pemasaran Carica tidak efisien karena farmer's share pada empat saluran pemasaran yang diterima petani masih kurang dari $40 \%$.

Kata kunci: Carica (Carica pubescens), efisiensi pemasaran, saluran pemasaran, SCP, usahatani

\footnotetext{
${ }^{1}$ Corresponding author:

Email: rally_anta@live.com
} 


\section{INTRODUCTION}

The tourism development in Wonosobo Regency, especially Dieng, becomes one of the most visited tourist attractions by local or foreign tourists. The addition of tourist objects such as Batu Ratapan Angin and Telaga Warna can increase tourists' interest in visiting Wonosobo Regency. The development of tourism areas encourages the development of the tourism support sector, such as developing local food and handicraft businesses using local raw materials. Based on the regional regulations of Wonosobo Regency No.8 Year 2017 concerning the tourism development master plan of Wonosobo Regency for 2017-2032. Wonosobo Regency has a special fruit commodity used as raw material for typical Wonosobo souvenirs, namely Carica or mountain papaya. Carica plants are used as intercropping plants because Carica plants can be used as soil erosion resistance (Azizi, 2018).

The choice of marketing channel affects the selling price received by farmers (Lawalata et al. (2017); Ghozali and Wibowo (2019). Table 1 shows the Carica marketing channels in April 2018. The selling price at the processing industry level was IDR4,119/kg. It was higher than the selling price at the collector level, while the lowest selling price was at the retailer level of IDR3,166/kg. The durability of fruit in a fresh state and the processing industry's demand affects the selection of marketing channels and selling prices.

Tabel 1. Marketing channels of Carica in April 2018

\begin{tabular}{lc}
\hline Marketing channel & Selling price (IDR/kg) \\
\hline Farmers - Processing Industry & 4,119 \\
Farmers - Village Collector & 3,454 \\
Farmers - Sub-district Collector & 3,718 \\
Farmers - Retailer & 3,166 \\
\hline
\end{tabular}

Source: Azizi (2018)

Coughlan et al. (2006) and Ahmad et al. (2018) stated that the right channel could be built in several methods to build an effective and efficient marketing channel. Farmers must choose the most profitable buyers to optimize their trading activities. However, one of the problems at this marketing stage is the difference in farmers' prices in each marketing channel. Farmers feel that the prices received from retailers and collector traders do not prosper farmers. So far, farmers have only played the role of price takers, and they have weak bargaining power. The weak bargaining position of farmers on the commodity Carica encourages farmers to switch to planting other commodities or intercropping in agricultural areas. The Carica fruit's low durability in fresh condition causes farmers to have a low bargaining position while harvesting (Rajanna et al. 2017). Because they do not have a strong bargaining position, farmers never feel the benefits motivating them to increase Carica production. The selling price of the Carica fruit is determined by the merchant.

Marketing channels can be analyzed using the structure conduct performance (SCP) method (Asmarantaka 2012; Dewi et al. 2017; Apituley et al. 2018). The market structure will describe the type and type of market formed so that the price determined follows the market type, whether monopoly, oligopoly, or perfect competition (Kustiari and Reni, 2017). In addition, the price has a very important role in determining the level of income earned by farmers, traders, and business organizations in general (Asefa et al. 2016 and Kumar et al. 2017). Therefore, marketing channels' analysis uses the market structure approach, market conduct, and market performance (SCP).

Information on marketing channels is important as a reference in managing Carica farming. The availability of selling price information in each marketing channel is expected to make farmers more optimal in producing Carica through more efficient use of inputs and choosing the right marketing channel to sell their crops. This study's objectives are divided into purpose; (1) to analyze the marketing channel of the Carica, (2) to analyze the efficiency of the marketing of the Carica in the Kejajar District, Wonosobo Regency. This research was conducted in Kejajar District, Wonosobo, Central Java Province, a center of Carica production in Central Java. The analysis was limited to analyze the marketing channels of Carica farming (Carica Pubescens) in Wonosobo District.

\section{METHODS}

The research was conducted in Kejajar District, Wonosobo Regency. This study's place was selected purposively in Kejajar District, Wonosobo Regency, with the consideration that Kejajar Subdistrict is a Carica center with a production of 4,589 tons (68\%) of the total Carica production in Wonosobo Regency. The research was conducted in October-November 2020, and it was the primary data collection stage. Primary data was obtained through direct interviews with the 
people involved in the Carica marketing system. The number of respondents drawn in this research consisted of 5 retailers, five village collectors, and five sub-district collectors. The respondents' total was determined by snowball sampling due to data farmers' and traders' limitations in marketing Carica. The application used for marketing channel analysis was Microsoft Excel.

Market structure analysis consists of institutions involved in marketing, market entry, and exit obstacles. Market concentration was seen from sales and payment mechanisms. The behavioral analysis includes; pricing method, payment system, number of marketing channels, and the presence or absence of collusion. Market performance analysis consists of:

Marketing margin (Alhusniduki, 2007)

$$
\mathrm{MP}=\mathrm{Pr}-\mathrm{Pf}
$$

Information: MP (Marketing Margin of Carica Fruit (IDR/ kg)); Pr (Price of Carica fruit at the merchant or retailer level (IDR/ kg)); Pf (Price of Carica fruit at the farmer or farmer level (IDR/ kg)).

Farmer's share (Alhusniduki, 2007)

$$
\mathrm{Fs}=\mathrm{Pf} / \operatorname{Pr} \times 100 \%
$$

Information: Fs (Farmer's share of Carica farming (in percentage)); Pr (Price of Carica at producer or trader level (IDR/ kg)); Pf (Price of Carica at farmer level (IDR/ kg)).

\section{Profit Ratio to Cost}

Profit ratio to cost $=\pi \mathrm{i} / \mathrm{Ci} \times 100 \%$

Information: Пi (Profits of the ith marketing agency); $\mathrm{Ci}$ (Cost of the ith marketing agency); i (institutions 1 , $2,3, \ldots$ etc).

The hypothesis of this research was the farmer's shared which receive by the farmer $\geq 40 \%$ and the Carica marketing channels in Kejajar District is operationally efficient.

This research aimed to find out Carica's marketing channel in Kejajar District. It used the market structure, market conduct, market performance (SCP) analysis method to see market conditions, the price formation process, and each institution's role in the Carica marketing channel. Analysis with the SCP method was also used to determine the value of marketing margin, farmer's share, and the ratio of profit to cost in the Carica marketing channel. Furthermore, the analysis of marketing efficiency was seen from the share value and the ratio of profits to farmers' costs in Kejajar District, Wonosobo Regency. Research framework in Figure1.

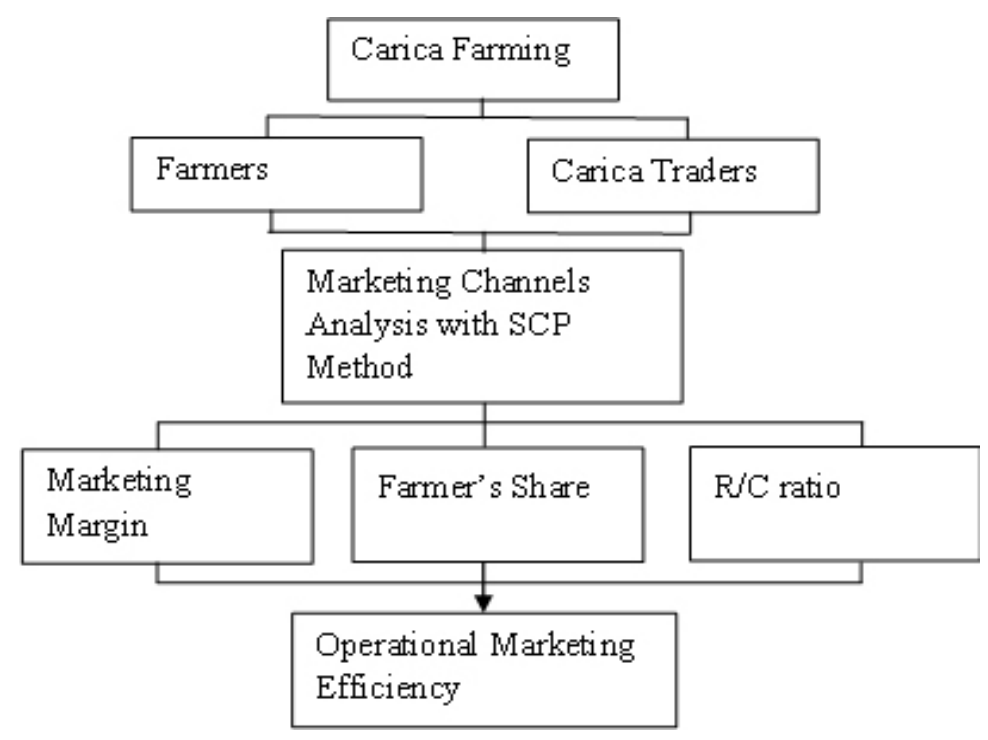

Figure 1. Research framework 


\section{RESULTS}

\section{Market Structure}

The market concentration of merchant collectors is seen from share Carica buying and selling activities. Retailers made the largest transactions with sales of $12,400 \mathrm{~kg}(41.10 \%)$, followed by sub-district collectors with $11,700 \mathrm{~kg}(38.74 \%)$ and village collectors of $6,100 \mathrm{~kg}(20.19 \%)$. Observations showed that market concentration was not only concentrated on a few collector traders and tended to be normally spread out. Pay later or debts made by 12 collecting traders, and those paying in cash were three collecting traders. Pay later or debts were made with an undetermined time limit because they were based on trust in the buyer. Collector traders showed that the obstacle to market entry was high because they require capital when entering the market. Capital in buying and selling Carica consists of a fleet of two-wheeled or four-wheeled vehicles for the purchase and sale of Carica. Availability of warehouse for sorting and storing Carica fruit before it was sold to the processing industry. It was considered to sufficient financial resources when buying Carica from fellow traders before reselling the Carica. The average financial capital used by traders in buying Carica activities until they were sold to processing industries was IDR3,370,000. In addition to the availability of capital, the Carica fruit's low durability in a fresh state increased the risk of entering the Carica buying and selling market.

The farm level's market structure can be seen from the number of sellers more than the number of buyers. The obstacles were the fruit condition that must be sold immediately because it was not durable, the bargaining position of the farmers was low, and the products offered were homogeneous. This characterizes that the market structure faced was classified as a purely competitive market. At the level of traders, the Carica market structure faced, it led to a pure oligopoly market structure. It can be seen from the number of sellers was less than the number of buyers, the conditions of the Carica being traded were homogeneous, and the barriers they had were high in terms of capital and the risk of fruit resistance. The results of the study were in line with Sari and Tamami (2020). Based on the SCP paradigm, an efficient market structure is a perfectly competitive market (Maina et al. (2015), Muthalib et al. (2017), and Puspitasari et al. (2020)). Perfectly competitive markets can create an efficient marketing system because perfect competition markets provide market participation incentives, such as producers, marketing institutions, and consumers (Rahim, 2007).

\section{Market Conduct}

Market conduct of Carica commodity was analyzed by observing sales and purchasing practices, pricing systems for pricing, and cooperation among marketing agencies. The institutions involved in marketing were:

\section{Carica farmer}

Wonosobo Regency is the center for the production of raw and processed Carica materials in Indonesia. This research was limited to Carica farmers located in the Kejajar district because the Kejajar sub-district is an area with the highest production compared to other sub-districts. All Carica farmers in this research (50 people) used their capital in their farming activities. The average capital spent by farmers for Carica cultivation was IDR400,000 per year, and it was relatively small in carrying out farming activities. The allocation of capital issued by farmers was small because it was easy to cultivate and it was not the main crop in the land area. The Carica was sold to several institutions at harvest period, depending on the agency that contacted them first.

\section{Retailer}

Retailers in the region generally bought Carica directly when farmers were active in the garden using a motorbike. Retailers in the region bought Carica in small quantities due to limited transportation means in the transportation process. This type of buyer was mostly found in Carica farmers who owned land far from public roads. The poor road conditions also burdened farmers with selling their crops. In this condition, Retailers' role in the region is important because they have a vehicle that can pass through difficult road terrain but is limited by their small ability to buy.

\section{Collecting Seller}

Collecting sellers were divided into village and district collectors. Seller from village bought Carica from farmers and then sold them to sub-district collectors or processing industries. Likewise, sellers from subdistrict bought Caricas from farmers, retailers, and sellers from the village and sell them to processing 
industries. The difference was the level of merchant collectors. The number of Carica purchased from farmers was $11,770 \mathrm{~kg}$, while retailers were only 3,870 $\mathrm{kg}$. The vehicles used by collectors could carry large quantities of Carica and had a warehouse for sorting Carica fruit.

\section{Process Industry}

The processing industry is the end of the Carica marketing channel because it has an important role in processing Carica. Thus, the fruit can be consumed. The production activities of processed Carica played a role in determining the price of Carica because it was related to the availability of raw materials and conditions of market demand for processed Carica. Carica fruit's characteristic that had low durability affected the sorting process, which should not take a long time. When sorting was complete, the fruit would be processed immediately or stored in the refrigerator if the fruit is not processed immediately.

The system of determining and paying prices at various marketing institutions applied $100 \%$ to each respondent farmer and trader. Carica's pricing mechanism was based on the condition of the fruit. The less fruit that was too ripe and the larger fruit, the higher the price. The research found that out of 50 respondents of Carica farmers who were interviewed, the selling price of Carica had been determined by traders concerning prices at other traders and processing industries. In addition, pricing could also be affected by the scarcity of goods and season. Market conduct in various marketing institutions can be seen in Table 2. The payment system along the channel was conducted by cash and receivable system. The cash payment system was carried out on transactions between traders, while transactions between farmers, retailers, and collectors from the village used the accounts receivable system.

33 Carica farmers $(66 \%)$ received the proceeds from selling Carica with the receivable system. The buyer's accounts receivable payment process was carried out (then becoming seller), who had been trusted by Carica farmers. There was trust between the two parties without any empirical evidence. The process of accounts payable was only based on the mutual trust of the two parties involved. Receipt of payments in cash or receivables did not affect the household income of Carica farmers. Carica commodity was a farm that provides additional income, and the main crop of potatoes which the main source of income. In the payment process, there were no other payment methods such as debit and credit. The observations also found no written contract or agreement in the buying and selling activities from farmers to traders and fellow buyers because the risk was too considerable for traders and processing industries. The thing to consider is the short durability of the fruit. There was no coercion between farmers and traders to continue transacting with 1 or 2 institutions only. All institutions in the Carica marketing channel were free to sell to any party, either to retailers, village collectors, sub-district collectors and processing industries. What limited the buying and selling process between one party and another was the improper price information.

Tabel 2. The system for determining and paying Carica in Kejajar district

\begin{tabular}{lllc}
\hline Marketing Channel & \multicolumn{1}{c}{ Observing sales } & Purchasing Practices & Pricing Systems \\
\hline Farmers & Retailers & Decided by Retailers & Debt \\
& Village Collectors & Decided by Village Collectors & Debt \\
& Sub-district Collectors & Decided by Sub-district Collectors & Cash \\
& Processing Industry & Decided by Processing Industry & Cash \\
Villager Collectors & Retailers & Decided by Retailers & Cash \\
& Sub-district Collectors & Decided by Sub-district Collectors & Cash \\
& Processing Industry & Decided by Processing Industry & Cash \\
Sub-district Collectors & Processing Industry & Decided by Processing Industry & Cash \\
Retailers & Processing Industry & Decided by Processing Industry & Cash \\
\hline
\end{tabular}


Observation result of Carica marketing channel in Kejajar District shows 6 channels in Carica marketing, as follow:

1. Farmers $\rightarrow$ processing industry

2. Farmers $\rightarrow$ retailers $\rightarrow$ processing industry

3. Farmers $\rightarrow$ village collectors $\rightarrow$ retailers $\rightarrow$ processing industry

4. Farmers $\rightarrow$ village collectors $\rightarrow$ processing industry

5. Farmers $\rightarrow$ village collectors $\rightarrow$ sub-district collectors $\rightarrow$ processing industries

6. Farmers $\rightarrow$ sub-district collectors $\rightarrow$ processing industry

Marketing channel analysis showed Carica distribution from farmers to processing industries/process manufacturing (Figure 2). The institutions involved in the Carica marketing channel were farmers, retailers, village collectors, sub-district collectors, and processing industries as the final destination of sales. The observations found that 26 farmers (52\%) sold their crops to village collectors, 11 farmers $(22 \%)$ sold to sub-district collectors, nine farmers $(18 \%)$ sold to retailers, while four farmers ( $8 \%$ ) the lowest percentage of those who sell their crops directly to the processing industry. The first channel was the shortest marketing channel compared to other marketing channels because it only involved two agencies in the distribution of Carica.

Channel I was the shortest channel because there were only two marketing agencies. In this channel, four farmers sold their Carica crops directly to the processing industry. The number of Caricas passing through this channel was $1,780 \mathrm{~kg}(7.91 \%)$. The average selling price of Carica on this channel was IDR1,900/ kg. Farmers who sold their crops directly to the processing industry were affected by family relations factors. The owners of the processing industry chose Carica raw materials from their own families. Thus, they could help in the process of selling their crops. The constraints faced were if the raw materials directly from the farmers were in the form of fruit that is too ripe and sometimes still raw. The size of the fruit was not evenly distributed because the sorting had not been done so that the processing industry had to re-sort.

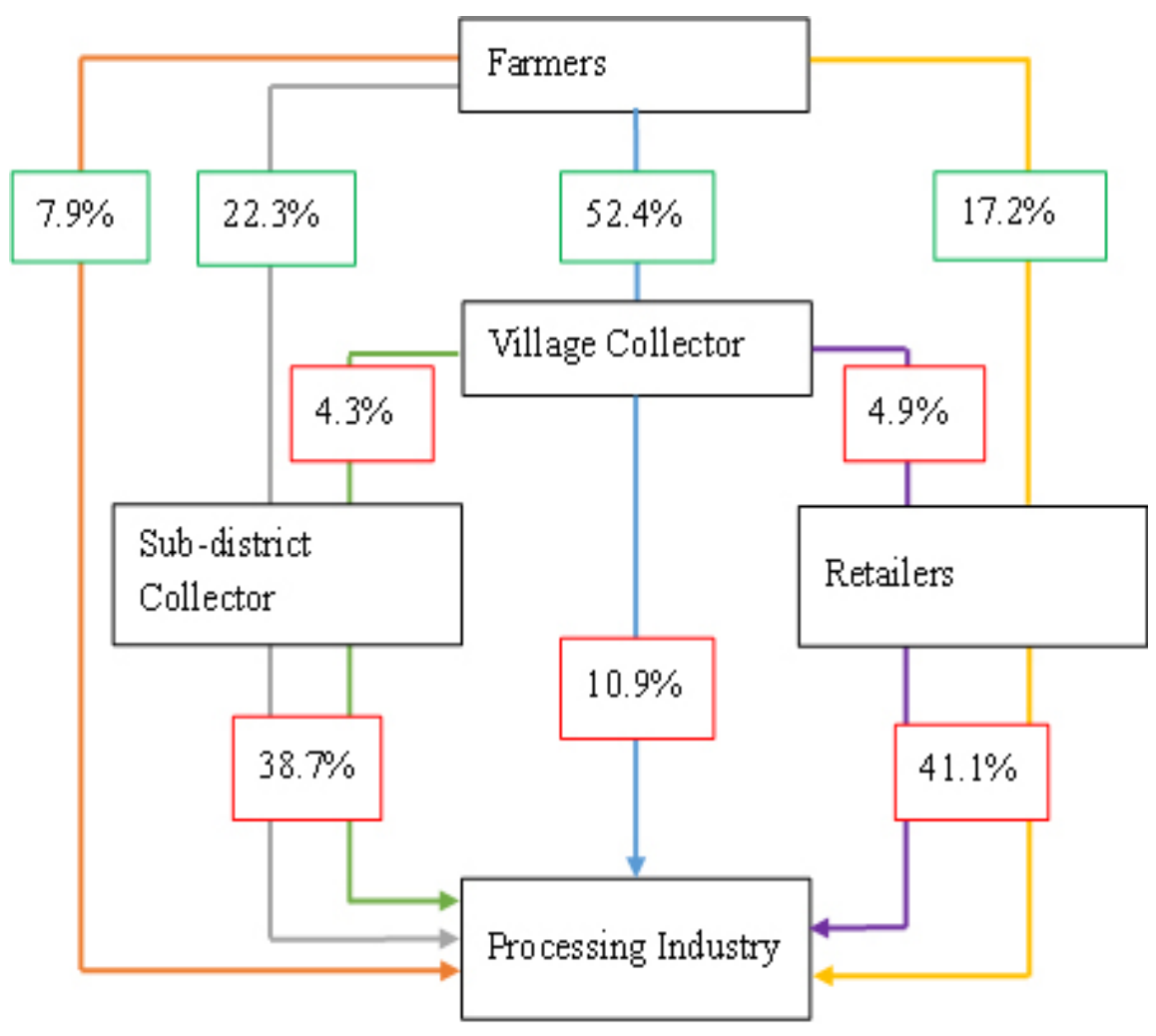

Information:

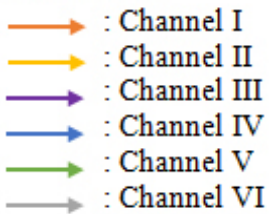

Figure 2. Marketing channels Carica in Kejajar District 
Channel II was the channel chosen by 9 Carica farmers in marketing their Carica. In this channel, farmers sold Carica to retailers of $3,870 \mathrm{~kg}(17.22 \%)$ and a selling price of IDR950/kg. Farmers who chose this channel were selling Carica because the land conditions were not strategic. Retailers were willing to buy and collect crops using motorized vehicles, but the retailer determines the price. Farmers had no choice but to sell their crops at a price offered by retailers. The durability of the fruit short and the activity of transporting it to another place of sale would provide additional costs. Therefore, farmers sold to retailers. Carica obtained by retailers would enter a sorting process based on size and level of maturity. The number of Carica fruit sold from retailers to the processing industry was $12,400 \mathrm{~kg}$ (41.10\%) for IDR2,480/kg.

Channel III, the role in the marketing channel had increased. It was village collectors. Field observations found that village collectors who sell Carica to retailers because the number of Caricas obtained by retailers from farmers had not met the target. Thus, they obtained additional from village collectors to meet the demand from the processing industry. Carica sold to retailers had gone through a sorting process. If they were not sorted, the selling price did not change too much from the purchase price from farmers. The number of Carica fruit sold to retailers was $1,500 \mathrm{~kg}(4.96 \%)$ with a selling price of around IDR2,000/kg.

Channel IV was the channel chosen by 26 Carica farmers because the location of the warehouse of village traders and farmers' land was not too far. The number of Caricas sold by farmers to village collectors was $11,770 \mathrm{~kg}(52.42 \%)$ for IDR1,030/kg. In this channel, some village collectors were willing to take the harvest directly to the land owned by the farmer. Carica sorting activities were conducted by part-time workers who were employed by collecting traders. The number of Carica sold was $3,300 \mathrm{~kg}$ (10.92\%), with an average selling price from village collectors to processing industries around IDR2,570/kg.

Channel V was a development of channel IV because of the additional role of sub-district collectors in the marketing channel. The Caricas that village collectors have sorted were sold to subdistrict collectors for as much as $1,300 \mathrm{~kg}(4.30 \%)$. Infield observations, the Caricas were sold to subdistrict collectors because of an insufficient Caricas stock at subdistrict collectors. Processing in the processing industry requires a certain amount of Carica to cover the shortage of stock. Sub-district collectors bought Carica from village collectors. The average selling price of Carica from village collectors to sub-district collectors was around IDR2,225/kg.

11 respondents chose channel VI as Carica farmers in marketing their crops. Sub-district collectors generally had large warehouses to carry out the sorting activities. Thus, they were able to accommodate large quantities of Carica before being sold to the processing industry. Sub-district collectors did not apply the minimum or maximum number of Carica purchased from various levels of marketing agencies. Any amount sold to subdistrict collectors would be accepted if the fruit was in good condition. The yields that were sold from farmers to sub-district collectors were $5,020 \mathrm{~kg}(22.34 \%)$. The selling price of Carica from farmers to sub-district collectors was IDR $1,277 / \mathrm{kg}$. If the sorting process of Carica from farmers had been carried out, it would be combined with the Carica obtained from retailers and village collectors. The total number of Carica sold to processing industries was $11,700 \mathrm{~kg}(38.74 \%)$ for IDR3,120/kg. The selling price from sub-district collectors to the processing industry was the highest because the sorting and grading processes were based on the demand of the intended processing industry.

\section{Market Performance}

\section{Marketing Margin}

Marketing margin analysis of Carica in each marketing channel could be used to see operational marketing efficiency. The amount of each margin can be seen from the description of Table 3 . The analysis results showed that from the six detected channels, it could be concluded that channel I had the lowest margin value with a value of IDR $0 / \mathrm{kg}$. The margin value was low because the farmers sell Carica directly to the processing industry without passing through other marketing agencies. The highest margin was found in channel $\mathrm{V}$ at IDR2,095/kg. The sorting activity of Carica fruit that retailers had carried out before being sold to subdistrict collectors. It affected marketing costs at the sub-district level of collector traders, which are not too high. Based on field observations, high marketing costs due to poor road conditions and land areas far from the main road affected transportation costs. The results of this analysis were also in line with the opinion of Kohls and Uhl (2002), Danil et al. (2014), Situmorang et al. 
(2015), and Nauly (2016), stating that the marketing margin of agricultural commodities was affected by the cost of transportation, the level of the purchase price, the amount of profit, working capital, and sales capacity. This is different from the research of Hoang (2015), Okoronknwo et al. (2016), and Rumallang et al. (2019), who found that marketing margins depend on the length of the marketing chain. The longer the marketing chain, the bigger the marketing margin. The price issued by each institution tended to be homogeneous, and there was not much difference in treatment in each institution for other institutions. The market price determined the level of the final price.
Farmer's share

Farmer's share is the comparison between the price received by farmers with the price paid by the end consumer. Farmer's share is also a quantitative measurement tool for assessing marketing efficiency, in which farmer's share is the share received by farmers expressed in percentage terms. A high farmer's share value indicated a high share received by farmers. Yet, this value did not absolutely indicate that the marketing system was efficient. This was related to the amount of added value given to a product by each marketing agency involved. Farmer's share value was inversely proportional to the marketing margin. It means that the higher the marketing margin formed, the smaller the share received by Carica farmers. The distribution of farmer's share of the Carica marketing channel in Kejajar District can be seen in Table 4.

Tabel 3. Marketing Margin of Carica in Kejajar District

\begin{tabular}{|c|c|c|c|c|c|c|}
\hline Information & Channel I & Channel II & Channel III & Channel IV & Channel V & Channel VI \\
\hline \multicolumn{7}{|l|}{ Farmers } \\
\hline Selling price & 1,900 & 950 & 1,025 & 1,025 & 1,025 & 1,277 \\
\hline Marketing costs & 200 & 0 & 0 & 0 & 0 & 0 \\
\hline Profit & 1,700 & 0 & 0 & 0 & 0 & 0 \\
\hline \multicolumn{7}{|l|}{ Village Collectors } \\
\hline Purchase price & 0 & 0 & 1,025 & 1,025 & 1,025 & 0 \\
\hline Selling price & 0 & 0 & 2,000 & 2,570 & 2,225 & 0 \\
\hline Marketing costs & 0 & 0 & 580 & 580 & 580 & 0 \\
\hline Profit & 0 & 0 & 395 & 965 & 620 & 0 \\
\hline Marketing margin & 0 & 0 & 975 & 1,545 & 1,200 & 0 \\
\hline \multicolumn{7}{|l|}{ Sub-district Collectors } \\
\hline Purchase price & 0 & 0 & 0 & 0 & 2,225 & 1,277 \\
\hline Selling price & 0 & 0 & 0 & 0 & 3,120 & 3,120 \\
\hline Marketing costs & 0 & 0 & 0 & 0 & 0 & 280 \\
\hline Profit & 0 & 0 & 0 & 0 & 895 & 1,563 \\
\hline Marketing margin & 0 & 0 & 0 & 0 & 895 & 1,843 \\
\hline \multicolumn{7}{|l|}{ Retailers } \\
\hline Purchase price & 0 & 950 & 2,000 & 0 & 0 & 0 \\
\hline Selling price & 0 & 2,480 & 3,00 & 0 & 0 & 0 \\
\hline Marketing costs & 0 & 680 & 0 & 0 & 0 & 0 \\
\hline Profit & 0 & 850 & 1,000 & 0 & 0 & 0 \\
\hline Marketing margin & 0 & 1,530 & 1,000 & 0 & 0 & 0 \\
\hline \multicolumn{7}{|l|}{ Processing Industry } \\
\hline Purchase price & 1,900 & 2,480 & 3,000 & 2,570 & 3,120 & 3,120 \\
\hline Total Marketing cost (IDR/kg) & 200 & 680 & 580 & 580 & 580 & 280 \\
\hline Total profit (IDR/kg) & 1,700 & 850 & 1,395 & 965 & 1,515 & 1,563 \\
\hline Total marketing margin (IDR/kg) & 0 & 1,530 & 1,975 & 1,545 & 2,095 & 1,843 \\
\hline Marketing margin percentage (\%) & 0 & 62 & 66 & 60 & 67 & 59 \\
\hline
\end{tabular}


Tabel 4. Distribution of famer's share value of Carica farming marketing channels in Kejajar District

\begin{tabular}{cccc} 
Channel & Prices at farm level $(\mathrm{IDR} / \mathrm{kg})$ & Prices at processing industry level (IDR/kg) & Farmer's share $(\%)$ \\
\hline I & 1,900 & 1,900 & 100 \\
II & 950 & 2,480 & 38 \\
III & 1,025 & 3,000 & 34 \\
IV & 1,025 & 2,570 & 39 \\
V & 1,025 & 3,120 & 32 \\
VI & 1,277 & 3,120 & 40 \\
\hline
\end{tabular}

Table 4 shows that marketing channel I had the highest farmer's share with a value of $100 \%$, followed by marketing channel VI with a value of $40 \%$. The high value of farmers' share indicated that Carica farmers in this channel obtained more profitable revenue than other marketing channels. Marketing channel V was Carica's marketing channel with the lowest farmer's share with a value of $32 \%$. This showed that the Carica marketing channel was directly profitable. Farmers only focused on cultivation activities until Carica harvest, while post-harvest activities that created marketing costs were not conducted. This was consistent with research conducted by Situmorang et al. (2015), Suprabowo et al. (2017), and Badriadi et al. (2020), in which the length of the marketing channel will have an impact on lower farmer's share.

\section{Profit ratio to cost}

Carica marketing in the Kejajar district showed that the lowest marketing cost was found in marketing channel I of IDR200/ $\mathrm{kg}$. This was due to the lack of marketing activities conducted. Thus, the costs incurred were low. It was different from marketing channel II or marketing channel III, in which the marketing function carried out by the marketing agency had been conducted. Carica marketing costs incurred as a result of marketing activities were quite high at IDR680/kg. Marketers generally spent marketing high Carica costs on sorting costs. This was due to the characteristics of the Carica that did not have long durability or decompose quickly.

The highest marketing profit was found in marketing channel I, while the lowest profit was found in marketing channel II. Profit ratio analysis showed that marketing channel I had the highest profit ratio with a value of 8.50 . It means that every IDR $1,000 / \mathrm{kg}$ spent on Carica marketing costs would provide an additional profit of IDR $8,500 / \mathrm{kg}$. The lowest profit-to-cost ratio was found in marketing channel II with a value of 1.25.
It means that every IDR $1,000 / \mathrm{kg}$ spent on marketing costs would provide an additional profit of IDR 1,250/ $\mathrm{kg}$. Distribution of the value of the profit ratio to cost of Carica farming marketing channels in Kejajar district in Table 5.

\section{Marketing Efficiency}

Based on quantitative analysis,Arelativelymoreefficient marketing channel was found in marketing channel I. It was assessed based on a relatively lower marketing margin, a relatively higher farmer's share value, and a profit-to-cost ratio greater than 1 . Channel I proved that Carica's marketing channel, shorter channels, provided a higher share than more extended channels with the marketing function performed relatively the same as other marketing channels (equivalent). The results of the analysis were in line with research conducted by Ali et al. (2015), Nzima and Dzanja (2015), Puspito et al. (2016), Jelliani and Yani (2019). Channel I could be an alternative for Carica farmers in selling their crops because it provided a relatively higher share price and market guarantees. However, post-harvest activities needed to be carried out. Thus, the harvested Carica met the processing industry's criteria, and the selling price was higher as the marketing costs of the Carica were added. Marketing Efficiency Value of Carica in Kejajar District in Table 6.

\section{Managerial Implications}

Farmers need to join the training of cultivation and post-harvest management. Post-harvest activities can influence the selling price of Carica. The improvement of marketing support facilities such as cold storage will help farmers face the risk of fruit that has short durability so the selling price can be stable from farmers to traders. An improved communication system for obtaining price information and road infrastructure will help farmers and traders buy and sell Carica. 
Table 5. Distribution of the value of the profit ratio to cost of Carica farming marketing channels in Kejajar district.

\begin{tabular}{cccc} 
Channel & Profit $(\mathrm{Rp} / \mathrm{kg})$ & Marketing Cost $(\mathrm{Rp} / \mathrm{kg})$ & Profit ratio to cost $(\pi / \mathrm{c})$ \\
\hline I & 1,700 & 200 & 8,50 \\
II & 850 & 680 & 1,25 \\
III & 1,395 & 580 & 2,40 \\
IV & 965 & 580 & 1,66 \\
V & 1,515 & 580 & 2,61 \\
VI & 1,563 & 280 & 5,58 \\
\hline
\end{tabular}

Table 6. Marketing efficiency value of Carica in Kejajar District

\begin{tabular}{cccc} 
Channel & Marketing margin (\%) & Farmer's share $(\%)$ & Profit ratio to cost $((\pi / \mathrm{c})$ \\
\hline I & 0 & 100 & 8.51 \\
II & 62 & 38 & 1.25 \\
III & 66 & 34 & 2.40 \\
IV & 60 & 39 & 1.66 \\
V & 67 & 32 & 2.61 \\
VI & 59 & 40 & 5.58 \\
\hline
\end{tabular}

\section{CONCLUSIONS AND RECOMMENDATIONS}

\section{Conclusions}

The marketing system of Carica in Kejajar District consists of 6 marketing channels involving some marketing institutions such as farmers, retailers, village collectors, sub-district collectors, and processing industries. Market conditions at the farmer level are perfect competition. However, it leads to an oligopoly at the seller level because the number of collectors is less than the number of processing industries that buy Carica. Many Carica farmers in the Kejajar district still use village collectors and retailers' services as intermediaries to sell their crops. This will have an impact on the price share received by farmers to be relatively lower.

Operational efficiency analysis of marketing shows that marketing channel I (farmers $\rightarrow$ processing industry) is a more efficient channel. This can be seen from the low marketing margin $(0 \%)$, higher farmer's share (1\%), and the profit earned was IDR8,500/kg for every IDR 1,000/ $\mathrm{kg}$ spent. The marketing efficiency analysis showed that the marketing of Carica onions in the Kejajar district was not operationally efficient because farmers' share is still below $40 \%$. This is following what was stated by Kohl and Uhl (2002), that in agricultural commodity marketing activities, the share of prices received by farmers should be up to $40 \%$ or more of the price paid by the end consumer.

\section{Recommendations}

Channel I (farmers $\rightarrow$ processing industry) located in Kejajar Subdistrict can be an alternative marketing channel that provides guaranteed market and fixed prices. Farmers are suggested to carry out post-harvest activities before selling them to the processing industry. Thus, the price is higher. In addition, it is necessary to analyze the added value and competitiveness of processed products Carica to know the development of marketing processed products Carica.

\section{REFERENCES}

Ahmad T, Daryanto A, Oktaviani R, Priyarsono DS. 2018. Global value chain of Indonesian pulp and paper industry. Jurnal Manajemen dan Agribisnis 15(2):118-128.https://doi.org/10.17358/ jma.15.2.118.

Alhusniduki. 2007. Alat dan Teknik untuk Memperbaiki Mutu. Jakarta: Higher Education Development Support Project.

Ali E, Talumingan C, Pangemanan PA, Kumaat RM. 2015. Efisiensi pemasaran bawang merah di Desa Tonsewer Kecamatan Tompaso Barat Kabupaten Minahasa. Jurnal Ilmiah Sosial Ekonomi Pertanian 11(2A): 21-32. https://doi. org/10.35791/agrsosek.11.2A.2015.9257.

Asmarantaka, R.W. 2012. Pemasaran Agribisnis (Agrimarketing). Bogor: Departemen Agribisnis. 
Fakultas Ekonomi dan Manajemen. Institut Pertanian Bogor.

Asefa S, Mulugeta W, Hadji J, Diro S. 2016. Factors affecting farmer's coffee market outlet preference in Southwest Ethiopia: survey result of coffee potential Districts of Jimma Zone. Journal of Marketing and Consumer Research 23(1):1122.

Apituley YMTN, Lopulalan Y, Salakory RA, Bawole D. 2018. Market structure, conduct and performance of SCAD (Decapterus russeli) in Kota Ambon. Jurnal Manajemen dan Agribisnis 15(3): 221229. https://doi.org/10.17358/jma.15.3.221.

Azizi, E.S. (2018). Analisis rantai pasok dan nilai tambah komoditas Carica di Desa Patakbanteng, Kecamatan Kejajar, Kabupaten Wonosobo [Skripsi]. Bogor: Institut Pertanian Bogor.

Badriadi, Fausayana I, Nalefo L. 2020. Analisis struktur, perilaku dan kinerja pasar rumput laut di Kabupaten Konawe Selatan. Jurnal Sosio Agribisnis 5(2): 50-61.

Coughlan, Anne T, Anderson E, Louis WS, Adel IE. 2006. Marketing Channel, Seventh Edition. New Jersey: Pearson Prentice Hall.

Dahl AD and Hammond 1977. Marker and Price Analysis the Agriculture Industries. New York: McGraw Hill.

Danil, Firdaus M, Hartoyo S. 2014. Produksi dan pemasaran kakao di Kabupaten Padang Pariaman, Provinsi Sumatera Barat. Jurnal Manajemen dan Agribisnis 11(1): 41-51.

Dewi N, Yusri J, Saputra AJ. 2017. Analisis struktur prilaku dan kinerja pasar komoditi padi di Desa Bunga Raya dan Kemuning Muda Kecamatan Bunga Raya Kabupaten Siak. Jurnal Agribisnis 19(1): 42-56. https://doi.org/10.31849/agr. v19i1.897.

Ghozali M R dan Wibowo R. 2019. Analisis risiko produksi usahatani bawang merah di Desa Petak Kecamatan Bagor Kabupaten Nganjuk. Jurnal Ekonomi Pertanian dan Agribisnis 3(2):294-310. https://doi.org/10.21776/ub.jepa.2019.003.02.7.

Hoang VV. 2015. Value chain analysis and competitiveness assessment of da xanh pomelo sector in Ben Tre, Vietnam. Asian Social Science 11(2):8-11. https://doi.org/10.5539/ass.v11n2p8.

Jelliani dan Yani R. 2019. Analisis saluran pemasaran dan kinerja pasar pala di Kabupaten Aceh Selatan. Jurnal Bisnis Tani 5(1): 43-48.

Kumar R, Verma VK, Sharma RC. 2017. Marketing and price spread of rice in Hanumangarh District of
Rajasthan. International Journal of Agriculture Innovations and Research 5(5): 697-702.

Kohls RL, Uhl JN. 2002. Marketing of Agricultural Products. Ninth Edition. New York: Macmillan Company.

Kustiari, Reni. 2017. Perilaku harga dan integrasi pasar bawang merah di Indonesia. Jurnal Agro Ekonomi 35(1): 77-87. https://doi.org/10.21082/ jae.v35n2.2017.77-87.

Lawalata M, Darwanto DH, Hartono S. 2017. Risiko Usahatani Bawang Merah di Kabupaten Bantul. Jurnal Agribisnis Sumatra Utara 10(1): 56-73. https://doi.org/10.31289/agrica.v10i2.924.

Maina CM. Lagat JK. Mutai BK. 2015. Effect of transaction costs on choice of mango marketing channel: the case of small scale farmers in Makueni County, Kenya. IOSR Journal of Agriculture and Veterinary Science 8(3):54-62.

Muthalib AA, Putra A, Nuryadi AM, Afiat MN. 2017. Seaweed business condition and marketing channels in CoastalDistrictofSoutheast Sulawesi. The International Journal of Engineering and Science (IJES) 6(10):2319- 1805.

Nauly D. 2016. Fluktuasi dan disparitas harga cabai di Indonesia. Jurnal Agrosains dan Teknologi 1(1): 56-69.

Nzima WM, Dzanja J. 2015. Efficiency of soybean markets in malawi: structure, conduct and performance approach. International Journal of Business and Social Science 6(4): 162-170.

Okoronknwo C, Simein CO, Samuel EO, Ikenna V E. 2016. Market participation and value chain of cassava farmers in Abia State. Journal of Scientific Research and Reports 12 (1): 1-11. https://doi.org/10.9734/JSRR/2016/27950.

Puspitasari A, Priyadi R, Sufyadi D. 2020. Struktur prilaku dan kinerja pemasaran cabai rawit merah di Kecamatan Cigalontang. Agribussines System Scientific Journal 1(1): 43-55. https://doi. org/10.20961/carakatani.v31i2.11954.

Puspito DP, Kusnandar, Setyowati N. 2016. Analisis rantai nilai ubi kayu di Kabupaten Pati. Journal of Sustainable Agriculture 31(2):94-101.

Rahim ABD, Hastuti DRD. 2007. Pengantar, Teori dan Kasus Ekonomika Pertanian. Jakarta: Penebar Swadaya.

Rajanna D. Bokelmann W. Gido EO. 2017. Smallholder vegetable farmers and marketing choices: implications for inclusiveness of farmers to markets. Asian Journal of Agricultural Extension, Economics \& Sociology 16(1): 1-10. https://doi. 
org/10.9734/AJAEES/2017/31683.

Rumallang A, Jumiati, Akbar, Nadir. 2019. Analisis struktur, perilaku dan kinerja pemasaran kentang di Desa Erelembang Kecamatan Tombolopao Kabupaten Gowa. Jurnal Agrikultura 30(3): 83-90. https://doi.org/10.24198/agrikultura. v30i3.23963.

Sari M, Tamami NDB. 2020. Struktur, perilaku dan kinerja usaha ronce melati rato ebhu di Desa Tunjung Kecamatan Burneh Kabupaten Bangkalan. AGRISCIENCE 1(1): 292-307.
Situmorang TS, Alamsyah, Zulkifli, Nainggolan S. 2015. Analisis efisiensi pemasaran sawi manis dengan pendekatan Structure, Conduct, and Performance (SCP) di Kecamatan Jambi Selatan Kota Jambi. Jurnal Sosio Ekonomika Bisnis 18(2):79-89. https://doi.org/10.22437/jiseb. v18i2.2830.

Suprabowo RL, Winandi R, Jahroh S. 2017. Analisis nilai tambah dan sistem pemasaran lidah buaya di Kabupaten Bogor. Jurnal Jamu Indonesia 2(3):102-113. https://doi.org/10.29244/jji. v2i3.39. 